Article

\title{
Genome-Based Insights into the Production of Carotenoids by Antarctic Bacteria, Planococcus sp. ANT_H30 and Rhodococcus sp. ANT_H53B
}

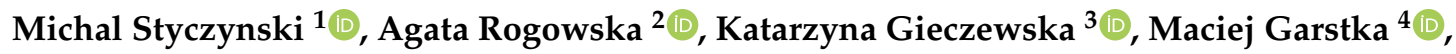 \\ Anna Szakiel ${ }^{2}$ (D) and Lukasz Dziewit ${ }^{1, *(\mathbb{D})}$ \\ 1 Department of Environmental Microbiology and Biotechnology, Institute of Microbiology, Faculty of Biology, \\ University of Warsaw, Miecznikowa 1, 02-096 Warsaw, Poland; mstyczynski@biol.uw.edu.pl \\ 2 Department of Plant Biochemistry, Institute of Biochemistry, Faculty of Biology, University of Warsaw, \\ Miecznikowa 1, 02-096 Warsaw, Poland; a.rogowska@biol.uw.edu.pl (A.R.); szakal@biol.uw.edu.pl (A.S.) \\ 3 Department of Plant Anatomy and Cytology, Institute of Experimental Plant Biology and Biotechnology, \\ Faculty of Biology, University of Warsaw, Miecznikowa 1, 02-096 Warsaw, Poland; \\ kat.gieczewska@biol.uw.edu.pl \\ 4 Department of Metabolic Regulation, Institute of Biochemistry, Faculty of Biology, University of Warsaw, \\ Miecznikowa 1, 02-096 Warsaw, Poland; garstka@biol.uw.edu.pl \\ * Correspondence: ldziewit@biol.uw.edu.pl; Tel.: +48-225-541-406
}

Academic Editors: Daniel Krug and Lena Keller

Received: 29 August 2020; Accepted: 21 September 2020; Published: 23 September 2020

\begin{abstract}
Antarctic regions are characterized by low temperatures and strong UV radiation. This harsh environment is inhabited by psychrophilic and psychrotolerant organisms, which have developed several adaptive features. In this study, we analyzed two Antarctic bacterial strains, Planococcus sp. ANT_H30 and Rhodococcus sp. ANT_H53B. The physiological analysis of these strains revealed their potential to produce various biotechnologically valuable secondary metabolites, including surfactants, siderophores, and orange pigments. The genomic characterization of ANT_H30 and ANT_H53B allowed the identification of genes responsible for the production of carotenoids and the in silico reconstruction of the pigment biosynthesis pathways. The complex manual annotation of the bacterial genomes revealed the metabolic potential to degrade a wide variety of compounds, including xenobiotics and waste materials. Carotenoids produced by these bacteria were analyzed chromatographically, and we proved their activity as scavengers of free radicals. The quantity of crude carotenoid extracts produced at two temperatures using various media was also determined. This was a step toward the optimization of carotenoid production by Antarctic bacteria on a larger scale.
\end{abstract}

Keywords: antarctica; carotenoid; Planococcus; Rhodococcus; secondary metabolite

\section{Introduction}

Microbial secondary metabolites are relatively low-molecular-mass products of the secondary metabolism that are usually produced during the late growth phase (i.e., idiophase). Secondary metabolites, like pigments, biosurfactants, antibiotics, and siderophores, are not essential for the growth of their producers; however, they may significantly increase the fitness and viability of organisms under specific environmental conditions [1].

One of the main threats to bacteria in the environment is the presence of solar radiation, which is highly variable over a range of scales and wavelengths. Ultraviolet-B (UV-B) radiation (315-280 nm) leads to direct DNA damage by inducing the production of photoproducts, such as cyclobutane pyrimidine dimers and pyrimidine-pyrimidone photoadducts. On the other hand, as a result of UV-A radiation (400-315 $\mathrm{nm}$ ), reactive oxygen species (ROS) form in the cell, which further leads to the 
damage of proteins, lipids, and nucleic acids [2]. The carotenoid pigments produced by bacteria, due to their specific structure and antioxidant properties, are the main agents preventing the harmful effects of UV radiation [3]. In permanently cold environments, such as Antarctica, where the temperature during the year is usually below zero and does not exceed $15^{\circ} \mathrm{C}$, carotenoids play a role in the modulation of the membrane fluidity and protect bacterial cells against disruption from freezing $[4,5]$.

There are many carotenoids of bacterial origin, including $\beta$-carotene, astaxanthin, and lycopene, that have found applications in the food industry, cosmetology, aquaculture, medicine, and in other industries [6]. In 2010, the global carotenoid market was valued at around \$1 billion with clear upward trends. The dominant carotenoid was $\beta$-carotene, with a $25 \%$ market share. However, the carotenoid with the highest market price was astaxanthin-at $\$ 2000 / \mathrm{kg}$ of synthetic and $\$ 7000 / \mathrm{kg}$ of natural pigment [7]. Importantly, synthetic carotenoids have some advantages over natural carotenoids. First, they show greater stability by limited undesirable oxidation or isomerization. In addition, they are prepared in more easily absorbable forms of colloids or water-soluble emulsions. However, carotenoids of synthetic origin may be contaminated with toxic substances that are used for their production that have a negative impact on human health. Therefore, the efficient production of natural carotenoids is particularly important and desired [5]. The growing market demands for carotenoids of natural origin forces biotechnological companies to look for efficient and alternative solutions to their acquisition.

The greatest challenge in the production of natural carotenoids is the high cost, including the energy outlays for maintaining the optimal growth temperatures of the commonly used mesophilic organisms. Therefore, psychrotolerant producers of bioactive compounds appear to be a promising solution, bringing direct economic benefits [8]. Zero waste and circular economy perspectives directed applied microbiology into the screening of microorganisms capable of producing desired metabolites from waste materials. This is another way to reduce the cost of carotenoid production [6,9]. Both of these goals can be achieved through genomic and functional analyses of psychrotolerant microorganisms from remote regions, like Antarctica, that can be an endless source of biotechnologically valuable organisms.

Bacteria of the genus Planococcus are aerobic, Gram-positive, motile cocci belonging to the Micrococcae family. These bacteria are common in various environments, often including extreme ones, such as the psychrosphere. Among Planococcus species, certain strains were recognized as producers of rare $C_{30}$ carotenoids. However, there remains relatively little information regarding the biosynthesis pathway of $\mathrm{C}_{30}$ carotenoids. On the other hand, these carotenoids are promising factors influencing stem cell proliferation, and they possess considerable antioxidative activity, which increases the attractiveness of these metabolites in biotechnology [10-12]. Planococcus spp. were also used as carotenoid producers from waste materials, like cellulose pulp, which may lower pigment production costs [13].

Another bacterial group that is interesting from the perspective of carotenoid production is Rhodococcus spp. Rhodococci are aerobic, Gram-positive, and nonmotile actinomycetes that belong to the Nocardiaceae family [14]. Bacteria from the Rhodococcus genus are very common in many environments and, similarly to the above mentioned Planococcus spp., they are common in extremely cold regions [15]. The metabolic abilities of the plethora of Rhodococcus species allow them to use many waste materials (e.g., lube oil [16], corn stover [17], or fruit pulp and peels [18]) as a carbon source during carotenoids production $[19,20]$.

In this study, we performed a thorough genomic analysis of two Antarctic bacteria, Planococcus sp. ANT_H30 and Rhodococcus sp. ANT_H53B, which were recognized as potential carotenoid producers. We aimed to identify the metabolic pathways responsible for carotenoid production that can be coupled with the results of biochemical analyses of the produced pigments. We tested the ability of both strains to produce carotenoids using waste materials. 


\section{Results and Discussion}

\subsection{General Physiological Characterization of Planococcus sp. ANT_H30 and Rhodococcus sp. ANT_H53B}

Both strains, i.e., Planococcus sp. ANT_H30 and Rhodococcus sp. ANT_H53B, originated from a collection of bacterial cultures that were previously isolated from soil samples taken in 2012 from King George Island (Antarctica, GPS coordinates: $62^{\circ} 09.601^{\prime} \mathrm{S}, 58^{\circ} 28.464^{\prime} \mathrm{W}$ ) [21]. The strains are orange pigmented (Figure 1), which suggested that they are carotenoid producers. The ANT_H30 strain is able to grow in a wide range of temperatures, ranging from 4 to $37^{\circ} \mathrm{C}$, tolerates $\mathrm{pH}$ between 4 and 11 , and is halotolerant, as it tolerates $\mathrm{NaCl}$ of up to $6 \%$. Rhodococcus sp. ANT_H53B is able to grow in temperatures from 4 to $30{ }^{\circ} \mathrm{C}$, it tolerates $\mathrm{pH}$ ranging between 5 and 12 , and is also halotolerant (tolerates up to $6 \%$ salinity). Besides carotenoids, both strains were screened for the production of other secondary metabolites. This demonstrated that ANT_H30, as well as ANT_H53B, possess the ability to produce siderophores or other compounds scavenging iron (Supplementary Figure S1). Additionally, in the case of ANT_H53B, the ability to produce surface-active compounds was detected. Bacteria cultivated in the lysogeny broth (LB) medium with the addition of vegetable oil $(1 \% w / v)$ lowered the interfacial tension (IFT) up to $25 \%$ (from $55( \pm 2)$ to $40( \pm 2) \mathrm{mN} / \mathrm{m}$ ).

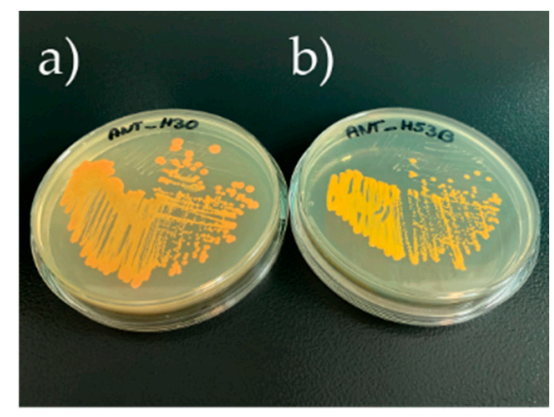

Figure 1. Orange pigmented Antarctic strains analyzed in this study: (a) Planococcus sp. ANT_H30 and (b) Rhodococcus sp. ANT_H53B. Bacteria were cultivated on agar-solidified lysogeny broth (LB) medium.

\subsection{Genomic Characterization of Bacterial Strains and Identification of Carotenoid Biosynthesis Gene Clusters}

\subsubsection{Genomes Sequencing and Overall Genomic Characterization}

Sequencing of the Planococcus sp. ANT_H30 and Rhodococcus sp. ANT_H53B genomes using the Illumina MiSeq platform generated 3,109,614 paired-reads and 932,291,246 nucleotides and 4,432,282 paired-reads and 1,333,091,924 nucleotides, respectively. As a result of the assembly of the Planococcus sp. ANT_H30 genome, 22 contigs of a total length of 3,636,638 bp were obtained. In the case of the assembly of the Rhodococcus sp. ANT_H53B genome, 37 contigs of a total length of 5,176,448 bp were generated. The genome sequences were initially automatically annotated using RAST on the PATRIC 3.6.2 web service, and the general features for both strains are presented in Table 1.

\subsubsection{Identification of Carotenoids Biosynthesis Gene Clusters}

Genomic analyses of Planococcus sp. ANT_H30 and Rhodococcus sp. ANT_H53B allowed the identification of genes related to the biosynthesis of carotenoids, i.e., crt genes (Table 2). In the ANT_H30 genome, the following genes were identified as a clustered unit- $\operatorname{crt} P, \operatorname{crtM}, \operatorname{crt} N, \operatorname{crtNc}$, and a single unclustered $\operatorname{crt} P$ gene (a second copy of $c r t P$; Figure 2). These genes are crucial in the production of $\mathrm{C}_{30}$ apocarotenoids, like 4,4'-diapolycopene and its derivatives (Figure 2), and are common in Planococcus species [22]. Apocarotenoid-producers are relatively rare among bacteria [23].

Within the genome of the ANT_H53B, we found eight crt genes, i.e., crtE, crtY,crtO,crtI (two copies), crtB, crtZ, and crtU. (Figure 2 and Table 2). The ANT_H53B strain possessed the crtE gene, which encodes geranylgeranyl diphosphate synthase, which is essential in the synthesis of $C_{40}$ carotenoids. In the case 
of ANT_H53B, as well as other rhodococci [20], the end products of the carotenoid biosynthetic pathway may potentially include various carotenoids or xanthophylls, including: echinenone, astaxanthin, hydroxyechineone, cryptoxanthin, chlorobactene, and isorenieratene (Figure 2).

\subsubsection{Genome-Based Insight into the Metabolic Potential}

Our analysis of the metabolic potential of the Planococcus sp. ANT_H30 strain revealed various metabolic modules of the carbohydrate metabolism, including the Embden-Meyerhof pathway of glycolysis, gluconeogenesis, the citrate cycle (Krebs cycle), the nonoxidative phase pentose phosphate pathway, and the Leloir pathway of galactose degradation. The ANT_H30 strain was shown to possess genes encoding enzymes involved in the degradation of fatty acids, ketone bodies, and amino acids, like valine, leucine, isoleucine, and lysine. Within the genome of Planococcus sp. ANT_H30, as well as other Planococcus strains (i.e., S5 [24], ZD22 [25], and PAMC21323 [26]), there are single genes (but not full pathways) encoding enzymes involved in the meta-cleavage of catechol compounds (catechol 2,3-dioxygenase (EC: 1.13.11.2) (GenBank accession number: FQ085_09110)) and in the degradation of several xenobiotics, such as benzoates and xylene (3-oxoadipate enol-lactonase (EC: 3.1.1.24) (GenBank accession number: FQ085_11270), 4-oxalocrotonate tautomerase (EC: 5.3.2.6) (GenBank accession number: FQ085_03925)), aminobenzoates and styrene (amidase (EC: 3.5.1.4) (GenBank accession number: FQ085_10470), 4-nitrophenyl phosphatase (EC: 3.1.3.41) (GenBank accession number: FQ085_11855)), ethylbenzene (acetyl coenzyme A (acetyl-CoA) acyltransferase (EC: 2.3.1.16) (GenBank accession number: FQ085_08820 and FQ085_11980)), and naphthalene (alcohol dehydrogenase (EC: 1.1.1.1) (GenBank accession number: FQ085_04180 and FQ085_12880)).

Some enzymes that take part in the degradation of halogenated compounds, such as dioxins, chloroalkanes, chloroalkenes, chlorocyclohexane, and chlorobenzene (e.g., aldehyde dehydrogenase $\left(\mathrm{NAD}^{+}\right)$ (EC: 1.2.1.3) (GenBank accession number: FQ085_01960 and FQ085_11355), formaldehyde dehydrogenase (EC: 1.2.1.46) (GenBank accession number: FQ085_14150), and 2-haloacid dehalogenase (EC: 3.8.1.2) (GenBank accession number: FQ085_08115)). In the genome of ANT_H30, cyanate lyase (EC: 4.2.1.104) (GenBank accession number: FQ085_05675), which participates in the breakdown of harmful cyanides into carbamate [27], and nitrilase (EC: 3.5.5.1) (GenBank accession number: FQ085_05485), which catalyses the hydrolysis of nitrile compounds [28], are also encoded. These enzymes take part in the degradation of toxic compounds into carboxylic acid and ammonia, which may constitute a potential source of carbon and nitrogen.

Table 1. General features of the Planococcus sp. ANT_H30 and Rhodococcus sp. ANT_H53B draft genomes.

\begin{tabular}{|c|c|c|}
\hline \multirow{2}{*}{$\begin{array}{c}\text { Feature } \\
\text { Strain }\end{array}$} & \multicolumn{2}{|c|}{ Calculation } \\
\hline & ANT_H30 & ANT_H53B \\
\hline Number of Contigs & 22 & 37 \\
\hline Estimated Genome Size (bp) & $3,636,638$ & $5,176,448$ \\
\hline GC Content $(\%)$ & $40.8 \%$ & $64.87 \%$ \\
\hline Number of Genes & 3591 & 4889 \\
\hline $\begin{array}{l}\text { Number of Proteins with } \\
\text { Functional Assignments }\end{array}$ & 2562 & 3379 \\
\hline $\begin{array}{c}\text { Number of Proteins with Enzyme } \\
\text { Commission (EC) Number } \\
\text { Assignments }\end{array}$ & 874 & 1149 \\
\hline $\begin{array}{c}\text { Number of Transfer RNA (tRNA) } \\
\text { Genes }\end{array}$ & 59 & 46 \\
\hline $\begin{array}{c}\text { Number of Regulatory RNA } \\
\text { Genes }\end{array}$ & 23 & 12 \\
\hline
\end{tabular}


Table 2. Carotenoid biosynthesis enzymes encoded by ANT_H30 and ANT_H53B.

\begin{tabular}{|c|c|c|c|c|c|}
\hline Strain & Gene & $\begin{array}{c}\text { GenBank Accession } \\
\text { Number }\end{array}$ & Encoded Protein & $\begin{array}{l}\text { Reference } \\
\text { Protein }\end{array}$ & $\begin{array}{l}\text { Amino Acids } \\
\text { Identity }\end{array}$ \\
\hline ANT_H30 & crtP & $\begin{array}{l}\text { FQ085_05070; } \\
\text { FQ085_10685 }\end{array}$ & $\begin{array}{c}\text { Diapolycopene oxygenase } \\
\text { (EC: } 1.14 .99 .44)\end{array}$ & $\begin{array}{l}\text { AUO94_02190; } \\
\text { AUO94_13335 }\end{array}$ & $\begin{array}{l}98 \% \\
98 \%\end{array}$ \\
\hline ANT_H30 & $\operatorname{crtM}$ & FQ085_05075 & $\begin{array}{l}\text { Dehydrosqualene synthase } \\
\text { (EC: } 2.5 .1 .96)\end{array}$ & AUO94_02185 & $98 \%$ \\
\hline ANT_H30 & $\operatorname{crtN}$ & FQ085_05080 & $\begin{array}{c}\text { Dehydrosqualene } \\
\text { desaturase (EC: } 1.3 .8 .2)\end{array}$ & AUO94_02180 & $98 \%$ \\
\hline ANT_H30 & $\operatorname{crtNc}$ & FQ085_05085 & $\begin{array}{c}\text { 4, } 4^{\prime} \text {-diapolycopene oxidase } \\
\text { (EC: } 1.14 .99 .44 \text { ) }\end{array}$ & AUO94_02175 & $98 \%$ \\
\hline ANT_H53B & $c r t E$ & FQ188_09125 & $\begin{array}{l}\text { Geranylgeranyl diphosphate } \\
\text { synthase (EC: } 2.5 .1 .29)\end{array}$ & NY08_684 & $95 \%$ \\
\hline ANT_H53B & $\operatorname{crt} Y$ & FQ188_06685 & $\begin{array}{l}\text { Lycopene beta-cyclase } \\
\text { (EC: } 5.5 .1 .19 \text { ) }\end{array}$ & NY08_1078 & $93 \%$ \\
\hline ANT_H53B & $\operatorname{crtO}$ & FQ188_09100 & $\begin{array}{l}\text { Beta-carotene ketolase } \\
\text { (EC: } 1.14 .99 .63)\end{array}$ & NY08_689 & $95 \%$ \\
\hline ANT_H53B & crtI & $\begin{array}{l}\text { FQ188_09130, } \\
\text { FQ188_15555 }\end{array}$ & $\begin{array}{l}\text { Phytoene dehydrogenase } \\
\text { (EC: } 1.14 .99 .-)\end{array}$ & $\begin{array}{l}\text { NY08_683; } \\
\text { NY08_2230 }\end{array}$ & $\begin{array}{l}94 \% \\
90 \%\end{array}$ \\
\hline ANT_H53B & $\operatorname{crt} B$ & FQ188_09140 & $\begin{array}{l}\text { Phytoene synthase } \\
\text { (EC: } 2.5 .1 .32 \text { ) }\end{array}$ & NY08_680 & $95 \%$ \\
\hline ANT_H53B & $\operatorname{crt} Z$ & FQ188_15555 & $\begin{array}{l}\text { Carotene hydroxylase } \\
\text { (EC: } 1.14 .13 .129)\end{array}$ & NY08_4121 & $95 \%$ \\
\hline ANT_H53B & crtU & FQ188_19840 & $\begin{array}{l}\text { Phi-Carotenoid synthase } \\
\text { (EC: } 1.3 .99 .39 \text { ) }\end{array}$ & NY08_3769 & $96 \%$ \\
\hline
\end{tabular}

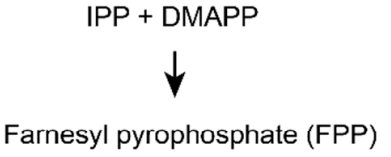

$\downarrow \mathrm{CrtM}$

4,4'-Diapophytoene

$$
\downarrow \text { CrtN }
$$

4,4'-Diapolycopene

$$
\downarrow \text { CrtP }
$$

4,4'-Diapolycopenedial

$$
\downarrow \mathrm{CrtNc}
$$

4,4'-Diapolycopenedioate

(a)

$$
\begin{array}{r}
\text { IPP + DMAPP } \\
\downarrow \text { CrtE }
\end{array}
$$

Geranylgeranyl diphosphate (GGPP)

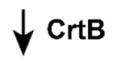

Phytoene

Adonixanthin

Astaxanthin<smiles>[AlH]C1CCC1</smiles>

$\uparrow \mathrm{Crtz}$

$\uparrow \mathrm{Crtz}$

Lycopene $\quad 3$ '-Hydroxyechinenone Phoenicoxanthin

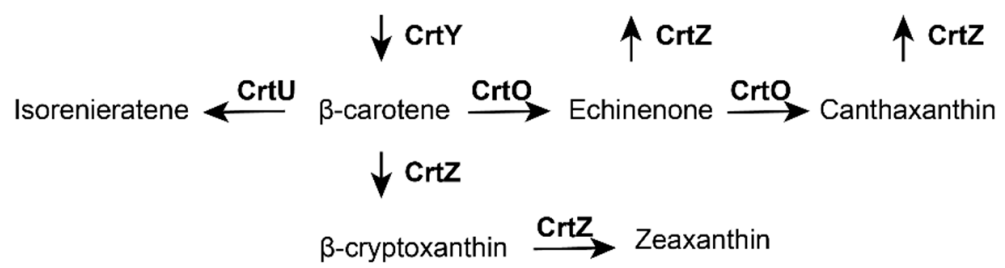

(b)

Figure 2. Genes and predicted carotenoid biosynthesis pathways of (a) Planococcus sp. ANT_H30 and (b) Rhodococcus sp. ANT_H53B. The following abbreviations mean: IPP, isopentenyl pyrophosphate; DMAPP, dimethylallyl pyrophosphate; $\mathrm{CrtP}$, diapolycopene oxygenase; $\mathrm{CrtM}$, dehydrosqualene synthase; $\mathrm{CrtN}$, dehydrosqualene desaturase; $\mathrm{CrtNc}$, 4,4'-diapolycopene oxidase; $\mathrm{CrtE}$, geranylgeranyl diphosphate synthase; $\mathrm{CrtY}$, lycopene beta-cyclase; $\mathrm{CrtO}$, beta-carotene ketolase; $\mathrm{CrtI}$, phytoene dehydrogenase; $\mathrm{CrtB}$, phytoene synthase; $\mathrm{CrtZ}$, carotene hydroxylase; $\mathrm{CrtU}$, phi-carotenoid synthase. 
The potential for utilization of various complex compounds and their usage as carbon and/or nitrogen sources is a huge advantage of using by-products or waste products for strain cultivation and desired metabolite production. In the genome of Planococcus ANT_H30, a number of genes related to siderophores synthesis were also found. Despite several ATP-binding cassette (ABC)-type $\mathrm{Fe}^{3+}$-siderophore transport systems (GenBank accession number: FQ085_00085, FQ085_13725, and FQ085_13730) there were genes encoding proteins responsible and crucial for staphylobactin-like siderophore production—SirA (GenBank accession number: FQ085_00100), SirB (FQ085_00095), and SirC (GenBank accession number: FQ085_00090).

We also analysed the metabolic potential of Rhodococcus sp. ANT_H53B. The genetic modules responsible for the basic carbohydrate metabolism were similar to ANT_H30, i.e., the Embden-Meyerhof pathway of glycolysis, gluconeogenesis, the citrate cycle (Krebs cycle), the non-oxidative phase pentose phosphate pathway, and the Leroir pathway of galactose degradation. Genes related with the oxidative phase pentose phosphate pathway, glycogen degradation, and propanoyl-CoA metabolism, as well as the degradation of fatty acids, ketone bodies, and acylglycerol (triacylglycerol lipase (EC: 3.1.1.3) (GenBank accession number: FQ188_10910)), were also present in the genome of ANT_H53B. Degradation pathways of amino acids, like valine, leucine, isoleucine, and lysine, were present.

Deeper genomic analyses revealed predicted abilities of ANT_H53B to obtain energy from dissimilatory nitrate reduction (i.e., nitrite reductase (NADH) (EC: 1.7.1.15) (GenBank accession number: FQ188_04565 and FQ188_06435)) and assimilatory sulfate reduction (i.e., phosphoadenosine phosphosulfate reductase (EC: 1.8.4.8) (GenBank accession number: FQ188_09865), sulfite reductase (ferredoxin) (EC: 1.8.7.1) (GenBank accession number: FQ188_09860), and sulfite reductase (NADPH) flavoprotein (EC: 1.8.1.2) (GenBank accession number: FQ188_10550 and FQ188_20710), which is common within Rhodococcus species (e.g., RB1 [29] and Eu-32 [30]). ANT_H53B possessed genes enabling the synthesis of cofactor F420 (i.e., 7,8-didemethyl-8-hydroxy-5-deazariboflavin (FO) synthase (EC: 4.3.1.32) (GenBank accession number: FQ188_19600), 2-phospho-L-lactate guanylyltransferase (EC: 2.7.7.68) (GenBank accession number: FQ188_05230), FO 2-phospho-L-lactate transferase (EC: 2.7.8.28) (GenBank accession number: FQ188_04305), and F420-0:L-glutamate ligase (EC: 6.3.2.31) (GenBank accession number: FQ188_04300)), involved in catalyzing a wide range of complex enzymatic redox reactions, which are widely distributed amongst archaeal methanogens and actinomycetes, including rhodococci [31,32].

Rhodococcus sp. ANT_H53B, as well as other described strains of this genus, e.g., P14 [33], 17895 [34] and RKJ300 [35], possess a wide spectrum of genes involved in the degradation of numerous hydrocarbons and xenobiotics. Genome analysis indicated the ability to degrade:

(i) benzoates and ethylbenzene-using e.g., 4-methoxybenzoate monooxygenase (EC: 1.14.99.15) (GenBank accession number: FQ188_15500), P-hydroxybenzoate 3-monooxygenase (EC: 1.14.13.2) (GenBank accession number: FQ188_16125), benzoate 1,2-dioxygenase (EC: 1.14.12.10) (GenBank accession number: FQ188_16155), protocatechuate 3,4-dioxygenase (EC: 1.13.11.3) (GenBank accession number: FQ188_10175), and hydroxyquinol 1,2-dioxygenase (EC: 1.13.11.37) (GenBank accession number: FQ188_18125);

(ii) aminobenzoates—with the use of amidase (EC: 3.5.1.4) (GenBank accession numbers: FQ188_09805, FQ188_11165, and FQ188_16180), and monooxygenase (EC: 1.14.13.-) (GenBank accession numbers: FQ188_11040 and FQ188_17850);

(iii) fluorobenzoates-using carboxymethylenebutenolidase (EC: 3.1.1.45) (GenBank accession numbers: FQ188_13875, FQ188_14120, FQ188_15865, and FQ188_18215);

(iv) toluene and xylene-using benzaldehyde dehydrogenase (EC: 1.2.1.28) (GenBank accession number: FQ188_11010), maleylacetate reductase (EC: 1.3.1.32) (GenBank accession number: FQ188_18130), and catechol 1,2-dioxygenase (EC: 1.13.11.1) (GenBank accession number: FQ188_16170); 
(v) nitro compounds, such as nitrotoluene, atrazine, caprolactam-using dihydropteridine reductase (EC: 1.5.1.34) (GenBank accession number: FQ188_00250), and $N$-ethylmaleimide reductase (GenBank accession number: FQ188_00250);

(vi) halogenated compounds, like dioxins, chloroalkanes, chloroalkenes, chlorocyclohexane, and chlorobenzene-using 2-haloacid dehalogenase (EC: 3.8.1.2) (GenBank accession numbers: FQ188_04145, FQ188_19570, and FQ188_19725), 2,4-dichlorophenol 6-monooxygenase (EC: 1.14.13.20) (GenBank accession numbers: FQ188_15475 and FQ188_18135).

In the genome of ANT_H53B, there were also genes indicating the ability to synthesize and transport siderophores, including several $\mathrm{ABC}$-type $\mathrm{Fe}^{3+}$-siderophore transport systems (GenBank accession numbers: FQ188_00500, FQ188_00505, FQ188_00510, FQ188_06045, FQ188_06050, and FQ188_06055), siderophore monooxygenase (GenBank accession number: FQ188_00495), and modules of non-ribosomal peptide synthetase (GenBank accession numbers: FQ188_00615, FQ188_03130, FQ188_03135, FQ188_03140, and FQ188_06210). ANT_H53B possesses genes responsible for the synthesis of trehalose-derived surfactants, typical for Rhodococcus species [36], i.e., trehalose-6-phosphate phosphatase (EC: 3.1.3.12) (GenBank accession numbers: FQ188_11590, FQ188_17500) and trehalose O-mycolyltransferase (EC 2.3.1.122) (GenBank accession numbers: FQ188_20530, FQ188_20535, and FQ188_20540), which increases the availability and, thus, utilization of hydrophobic substrates.

\subsubsection{Biosafety Considerations of Planococcus sp. ANT_H30 and Rhodococcus sp. ANT_H53B}

The Planococcus and Rhodococcus species are very common in various environments. So far, no pathogens from the genus Planococcus have been reported, while, within the genus Rhodococcus, two pathogenic species, R. fascians and R. equi-infecting plants [37] and mammals [38], respectively-were found. As both strains analyzed in this study can be potentially applied in biotechnological processes, it is necessary to analyse their biosafety. The genomic analysis of Planococcus sp. ANT_H30 genome using the Resistance Gene Identifier (RGI) analyzer indicated the absence of antibiotic resistance genes, while in the case of Rhodococcus sp. ANT_H53B, this revealed the presence of a putative rifampicin resistance gene, $R b p A$ (encoding RNA polymerase (RNAP)-binding protein, whose presence increased the tolerance levels of mycobacteria to rifampicin by an unknown mechanism) with 100\% similarity to protein WP_027497120 [39]. To determine whether the predicted antibiotic resistance gene was truly associated with the resistance phenotype, we tested the MIC (minimum inhibitory concentration) of rifampicin resistance. The result revealed the sensitivity to the tested antibiotic (MIC was lower than $0.016 \mathrm{mg} / \mathrm{L}$ of rifampicin concentration).

In addition, single genes potentially related to virulence were detected in the genomes of both strains. In the genome of ANT_H30, there was a clpP gene (GenBank accession number: FQ085_12085) that encodes the ATP-dependent Clp protease proteolytic subunit of ClpP (EC: 3.4.21.92). Clp proteolytic complexes are responsible for the adaptation of bacteria to stress by degrading accumulated and misfolded proteins but were also reported as putative virulence factors [40]. In the case of ANT_H53B, the $i c l$ gene (GenBank accession number: FQ188_12695) was identified as a virulence factor. The $i c l$ gene encodes isocitrate lyase (EC: 4.1.3.1), which is an important virulence factor of, e.g., pathogenic R. equi. Isocitrate lyase contributes to the acquisition of membrane lipid-derived fatty acids [41].

\subsection{Chemical Identification of Synthesized Carotenoids}

The ultraperformance liquid chromatography (UPLC) analyses of the carotenoid extract from the ANT_H30 strain revealed the presence of two potential carotenoids. They demonstrated relatively large masses, i.e., 857.5498 and $871.5688 \mathrm{Da}$, which cannot be assigned to any known carotenoids. However, they have the spectra characteristics of carotenoids $(289 \mathrm{~nm} ; 468 \mathrm{~nm} ; 495 \mathrm{~nm}$ and $289 \mathrm{~nm} ; 468 \mathrm{~nm}$; $494 \mathrm{~nm}$; Supplementary Table S2). The inability to precisely identify carotenoids from ANT_H30 extract may be due to the ability of carotenoids to aggregate or form connections with lipids [42]. Planococcus sp. ANT_H30 is an Antarctic strain, and the specific placement of carotenoids for cryoprotective purposes 
may contribute to significant modifications in the structure of carotenoids [4]. Therefore, it is possible that novel carotenoids were found; however, this requires further investigation.

For ANT_H53B, a mixture of six different carotenoids was identified (Supplementary Table S2). Among them, we accurately determined the presence of two compounds, i.e., dihydroxyneurosporene and hydroxyechinenone, and this was also partially confirmed by genomic analyses. As a result of the gas chromatography-mass spectrometry (GC-MS) analysis, mass ions of 587.91, 575.46, and 577.48 Da with retention times of 27.994, 33.311, and $33.121 \mathrm{~min}$, respectively (Supplementary Figure S2), were present in the carotenoid extract from ANT_H53B. This result confirmed the presence of dihydroxyneurosporene (575.4602 Da) and two other (not identified by name) carotenoids (i.e., 587.9095 and 577.4785 Da) found using UPLC. For ANT_H53B, the presence of carotenoid with a mass of $536.87 \mathrm{Da}$, correlated with lycopene or beta-carotene mass was also confirmed.

\subsection{Free Radical Scavenging Activity}

One of the main advantages of carotenoids is their distinctive, polyunsaturated chemical formula. This feature determines their ability to scavenge free radicals, and thus carotenoids constitute the desired metabolite in the food, pharmaceutical, and medicine industries. The antioxidant potencies of the ANT_H30 and AND_H53B carotenoid extracts were evaluated by the DPPH (2,2-diphenyl-1-picrylhydrazyl) method [43], which enabled us to measure the free radical scavenging ability.

The scavenging effect was tested on a $0.1 \mathrm{mM}$ DPPH solution (used as a free radical) and revealed the $\mathrm{IC}_{50}$ values (antioxidant concentration required for quenching 50\% of the initial DPPH) were $3.2 \mu \mathrm{g} / \mathrm{mL}$ and $0.96 \mu \mathrm{g} / \mathrm{mL}$ for the extracts obtained from ANT_H30 and ANT_H53B, respectively. It was shown that ANT_H30 quenched 50\% and ANT_H53B 77\% of the DPPH maximally (Figure 3). These results indicate a high antioxidant capacity of both crude carotenoid extracts; however, the higher scavenging activity was proven for carotenoids produced by ANT_H53B.

\subsection{Optimization of Production of Carotenoids}

The optimization of the production of carotenoids in the ANT_H30 and ANT_H53B strains was performed using various growth media (including minimal medium supplemented with cheap industrial byproducts, i.e., molasses and yeast extract) and at various temperatures (Figure 4).

After four days of cultivation of ANT_H30 at $15^{\circ} \mathrm{C}$ in LB medium, the bacteria produced $0.228 \mathrm{mg}$ $( \pm 0.008)$ of crude carotenoid extract per gram of dry biomass (gdb). On the other hand, this strain also synthesized a significant amount of carotenoids on M9 (minimal) medium supplemented with yeast extract $(\mathrm{M} 9+\mathrm{YE})$. In this case, the result was $0.088 \mathrm{mg}( \pm 0.009) / \mathrm{gdb}$ after four days of cultivation. Although this result is almost 2.5-times lower when compared with the cultivation on LB medium, it should be emphasized that yeast extract is an easily accessible industrial byproduct. However, ANT_H30 cultivated in M9 medium supplemented with molasses (M9 + MOL) in $15^{\circ} \mathrm{C}$ produced only $0.042 \mathrm{mg}( \pm 0.003)$ of carotenoids/gdb after four days of cultivation, which is almost two-times lower than in the case of M9 + YE and as much as 5.5-times lower than for LB cultures.

The ANT_H30 strain is a psychrotolerant, however, also demonstrated good growth at higher temperatures. In order to determine the carotenoid production efficiency at higher temperatures, ANT_H30 was cultivated at $25^{\circ} \mathrm{C}$. This revealed a similar capacity to produce biomass and carotenoids as at $15{ }^{\circ} \mathrm{C}$. After four days of cultivation of ANT_H30 in LB and M9 + YE at $15{ }^{\circ} \mathrm{C}$, the amounts of carotenoids reached, respectively, $0.221 \mathrm{mg}( \pm 0.035) / \mathrm{gdb}$ and $0.082 \mathrm{mg}( \pm 0.009) / \mathrm{gdb}$. However, in the case of M9 + MOL, the amount was significantly lower $(0.015( \pm 0.002) / \mathrm{gdb})$. This result suggests that ANT_H30 can be cultivated and potentially used for carotenoids production, at low temperatures, which may reduce the overall costs of pigment biosynthesis. 


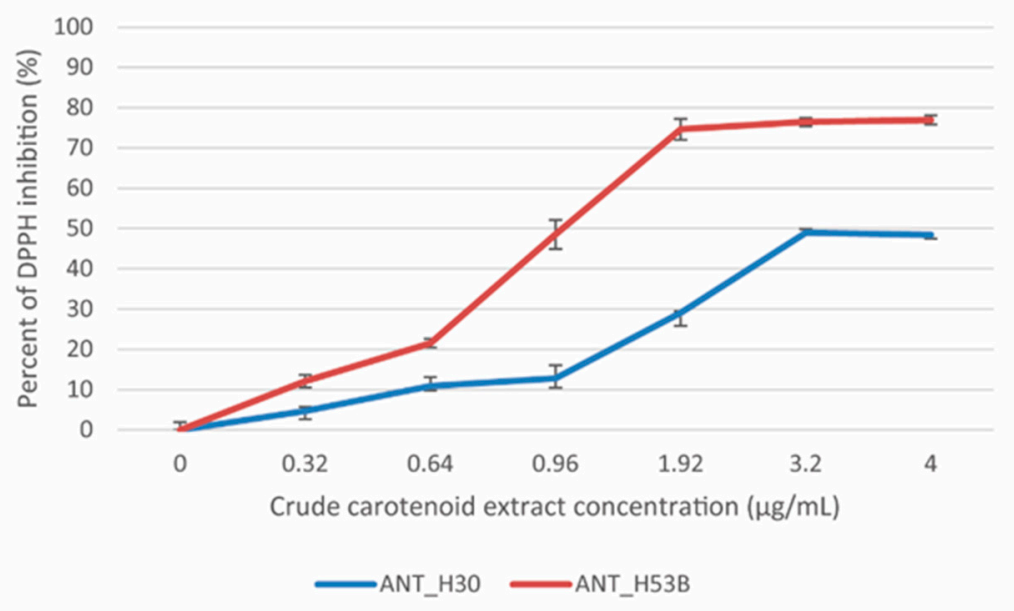

Figure 3. DPPH inhibition test performed using the ANT_H30 and ANT_H53B crude carotenoid extracts. Error bars represent standard deviations of the triplicates.

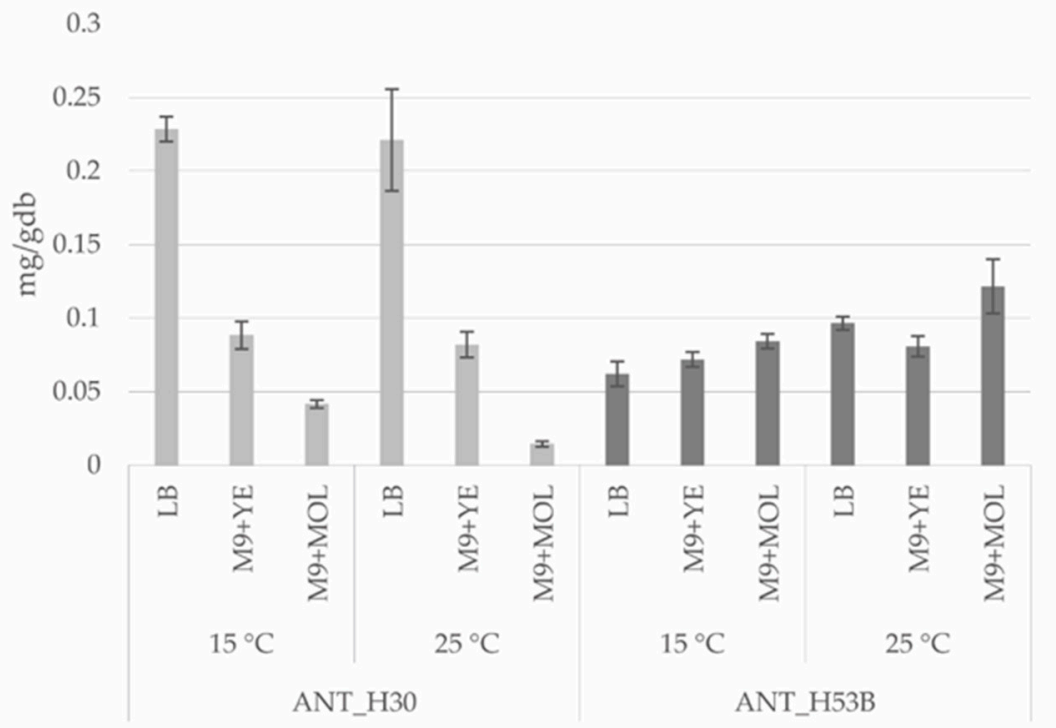

Figure 4. The quantity of extracted crude carotenoids from Planococcus sp. ANT_H30 and Rhodococcus sp. ANT_H53B cultivated in various media and at various temperatures.

The results for the ANT_H53B strain differed significantly. After four days of cultivation in LB medium at $15{ }^{\circ} \mathrm{C}$, the amount of crude carotenoid extract reached $0.062 \mathrm{mg}( \pm 0.008) / \mathrm{gdb}$. A similar result was obtained for ANT_H53B cultivated in M9 + YE, i.e., $0.072( \pm 0.005) / g d b$. The best conditions for carotenoid production were obtained when cultivating in $\mathrm{M} 9+\mathrm{MOL}$ medium at $15^{\circ} \mathrm{C}$. After four days of cultivation, the amount of desired metabolites was $0.084 \mathrm{mg}( \pm 0.005) / \mathrm{gdb}$. The production of carotenoids by ANT_H53B at a higher temperature $\left(25^{\circ} \mathrm{C}\right)$ resulted in similar amounts, i.e., $0.1 \mathrm{mg}( \pm 0.005) / \mathrm{gdb}$ and $0.08 \mathrm{mg}( \pm 0.007) / \mathrm{gdb}$ for LB and M9 + YE cultures, respectively. A significant increase of carotenoid production was achieved for cultures in $\mathrm{M} 9+\mathrm{MOL}$ at $25^{\circ} \mathrm{C}$ and the amount of orange pigments reached $0.122 \mathrm{mg}( \pm 0.018) / \mathrm{gdb}$.

Asker et al. [44] determined the production of carotenoids (per gram of dry biomass) from a number of mesophilic bacterial strains belonging to the classes Flavobacteria, Sphingobacteria, Alphaproteobacteria, Gammaproteobacteria, Actinobacteria, Bacilli, and Deinococci. Among 104 strains of carotenoid-producing bacteria, only a few isolates were recognized as efficient carotenoid producers, i.e., Pedobacter sp. TDMA-5 (0.8 mg/gdb), Brevudimonas sp. TDMA-7 (1.4 mg/gdb), Paracoccus sp. 
TDMA-8 (1.1 mg/gdb), and two strains of Sphingomonas genus-TDMA-16 (1.7 mg/gdb) and TDMA-17 $(2.8 \mathrm{mg} / \mathrm{gdb})$. On the other hand, Vila et al. [45] examined strains isolated from King George Island for carotenoid production. In this study, the production of carotenoids oscillated around $0.5 \mathrm{mg} / \mathrm{gdb}$ for Planococcus sp. P48, while for Arthrobacter sp. P40 and Cryobacterium sp. P19 it was around $0.3 \mathrm{mg} / \mathrm{gdb}$ and $0.4 \mathrm{mg} / \mathrm{gdb}$, respectively.

Currently, in industry, two groups of strains are used for the production of carotenoids, i.e., natural (unmodified, environmental isolates) and genetically modified strains. These genetically modified strains are able to produce a much higher amount of carotenoids (e.g., around $12 \mathrm{mg} / \mathrm{gdb}$ carotenoids from the modified Escherichia coli [46]). However, these are genetically modified strains and their usage may be restricted. As for the natural, environmental isolates used in an industry this production yield is usually much lower. For example, Brevundimonas sp. N-5, recognized as a very efficient producer of carotenoids, synthesized around $0.6 \mathrm{mg} / \mathrm{gdb}$ [47]. Therefore, the strains ANT_H30 and ANT_H53B, described in this study, may be recognized as moderately efficient producers of carotenoids. However, a considerable advantage of both strains is their ability to produce biomass (and carotenoids) at low temperature, which may significantly reduce the costs of pigments production. Additionally, we proved that they can use cheap waste products (e.g., molasses) for the production of biomass, which also may further reduce the production costs.

\section{Materials and Methods}

\subsection{Bacterial Strains and Culture Conditions}

The bacterial strains were cultivated in lysogeny broth (LB) and minimal medium M9 [48], supplemented $(0.5 \%(w / v))$ with various carbon sources (i.e., yeast extract and beet molasses) at $15{ }^{\circ} \mathrm{C}$ and $25^{\circ} \mathrm{C}$ with rotary shaking set to $150 \mathrm{rpm}$. The growth kinetics were assessed by measuring the changes in the optical density of cultures in comparison with the noninoculated controls, using an automated microplate reader (Sunrise TECAN, Tecan Trading AG, Männedorf, Switzerland). Before inoculation of the supplemented M9 medium, the bacteria were cultivated overnight in LB medium at the optimal growth temperature $\left(15^{\circ} \mathrm{C}\right)$. Overnight cultures were then centrifuged $(6000 \mathrm{rpm}$ for $5 \mathrm{~min})$ and washed three times with $0.85 \%$ saline solution. Next, the bacteria were diluted in triplicate, into the fresh M9 medium supplemented with an appropriate carbon source. In each case, the initial optical density at $600 \mathrm{~nm}\left(\mathrm{OD}_{600}\right)$ was 0.05 . The $\mathrm{OD}_{600}$ of the respective cultures was measured every $24 \mathrm{~h}$ for five days.

\subsection{Detection of Siderophores and Surfactants}

To determine the ability to produce siderophores and/or other iron scavenging compounds, bacteria were cultivated on the GASN medium [49] for 4 days at $20{ }^{\circ} \mathrm{C}$ with rotary shaking set to $150 \mathrm{rpm}$. Bacteria were then centrifuged (6000 rpm/5 min) and the obtained supernatants were added in a 1:1 ratio to the CAS reagent [50]. GASN medium was used as a negative control, while deferoxamine mesylate salt (Sigma-Aldrich Co., St. Louis, MO, USA), at a concentration of $0.025 \mathrm{mM}$, was used as a positive control. All experiments were performed in triplicates. After an hour of incubation, the absorbance at $630 \mathrm{~nm}$ was measured using an automated microplate reader (Sunrise TECAN; Supplementary Figure S1).

\subsection{Draft Genome Sequencing}

Genomic DNAs of the Planococcus sp. ANT_H30 and Rhodococcus sp. ANT_H53B were isolated using the CTAB (cetyl trimethylammonium bromide)/lysozyme) method [51]. An Illumina TruSeq library was constructed following the manufacturer's instructions. The genomic libraries were sequenced on an Illumina MiSeq instrument (using the v3 chemistry kit; Illumina, San Diego, CA, USA) in the DNA Sequencing and Oligonucleotide Synthesis Laboratory (oligo.pl) at the Institute of Biochemistry and Biophysics, Polish Academy of Sciences, Warsaw. The reads trimmed with 
CutAdapt v. 1.9.1 [52] were further assembled using Newbler De Novo Assembler v. 3.0 (Roche, Basel, Switzerland).

\subsection{Bioinformatics}

The Planococcus sp. ANT_H30 and Rhodococcus sp. ANT_H53B genomes were manually annotated using the MAISEN platform and automatically annotated using RAST [53] on the PATRIC 3.6.2 [54] web service. Similarity searches were performed using BLAST programs [55]. The metabolic features were identified with the SEED viewer web server [56], KEGG (Kyoto Encyclopedia of Genes and Genomes) Automatic Annotation System (KAAS) database [57], and the bacterial version of the antiSmash web server [58]. All options were selected with the default parameters. Additionally, for deeper metabolic investigation, the amino acid sequences were subjected to BLAST-KOALA analysis [59]. The KO (KEGG Orthology) assignments were performed using a modified version of the internally used KOALA (KEGG Orthology And Links Annotation) algorithm (BLAST-KOALA) after the BLAST search against a nonredundant dataset of pangenome sequences [59]. To investigate the virulence factors of the tested strains, the VFDB database (Virulence Factors Database) was used [60].

To identify putative antibiotic resistance genes, we used the Resistance Gene Identifier (RGI) in the Comprehensive Antibiotic Resistance Database (CARD) [61] software. Hits showing at least 50\% identity with the reference protein were considered significant. Each hit was verified manually using BLASTp analysis.

\subsection{Antibiotic Susceptibility Testing}

To determine the rifampicin susceptibility pattern of tested bacteria, the MIC of this antibiotic was assessed using Etest ${ }^{\mathrm{TM}}$ (Liofilchem, Roseto degli Abruzzi, Italy). The analysis was conducted according to the European Committee on Antimicrobial Susceptibility Testing (EUCAST) recommendations [62].

\subsection{Extraction of Carotenoids from Bacterial Culture}

The extraction of nonpolar lipids from Planococcus sp. ANT_H30 and Rhodococcus sp. ANT_H53B was conducted in a climate room at $4{ }^{\circ} \mathrm{C}$. We transferred $0.5 \mathrm{~mL}$ of a centrifuged suspension of bacteria to a $45 \mathrm{~mL}$ Corex tube and, after the addition of $4 \mathrm{~mL}$ of methanol, sonicated the sample with an ultrasonic cleaner (Sharpertek ${ }^{\circledR}$, Pontiac, MI, USA) for $15 \mathrm{~min}$. Then, another $5 \mathrm{~mL}$ of methanol was added and the sample was shaken in a reciprocating shaker (PROMAX 2020, Heidolph, Germany) for 15 min. After shaking, the sample was stored without agitation in the refrigerator $\left(-12^{\circ} \mathrm{C}\right)$ for $15-20 \mathrm{~min}$ to allow the dregs to descend. The clear methanol phase was transferred to another Corex tube, and the whole process was repeated until the bacterial suspension was discolored (typically 2-3 times). The combined methanol extracts were filtered through a Millipore syringe filter unit Millex-CV13 Filter Unit $(0.22 \mu \mathrm{m})$, evaporated to dryness under argon at $35^{\circ} \mathrm{C}$ and dissolved in $1 \mathrm{~mL}$ methanol-propanol-hexane $6: 1: 3(\mathrm{v} / \mathrm{v} / \mathrm{v})$ mixture. Before the UPLC analysis, the samples were stored under argon at $-70^{\circ} \mathrm{C}$.

\subsection{Qualitative Analysis of Carotenoids}

\subsubsection{Ultraperformance Liquid Chromatography (UPLC)}

The carotenoid compositions were analyzed by a modified method described previously [63]. The extracted pigments were separated using the Acquity Ultra Performance LC system (Waters, Milford, MA, USA) connected with the Synapt G2 HDMS mass spectrometer (Waters). The samples were injected $(7.5 \mu \mathrm{L})$ into an Acquity UPLC HSS T3 $(1.8 \mathrm{~mm}, 1.0 \times 150 \mathrm{~mm})$ analytical column. Initially, the column was eluted at $25{ }^{\circ} \mathrm{C}$ at a constant flow rate of $35 \mu \mathrm{L} / \mathrm{min}$ with $100 \%$ of solvent A (water-methanol 15:85, v/v) and, after injection at the same condition, for the next $15 \mathrm{~min}$. Next, the stepped linear gradient of buffer B (methanol/2-propanol/hexane 2:1:1, v/v) was distributed as follows: $0-15 \%$ B at $15-160 \mathrm{~min}$ (flow rate $=35 \mu \mathrm{L} / \mathrm{min}$ ); $15 \%-80 \%$ B at $160-240 \mathrm{~min}$ (flow rate $=$ $35-20 \mu \mathrm{L} / \mathrm{min}$ ); $80 \%-90 \%$ B at $240-245 \mathrm{~min}$ (flow rate $=20 \mu \mathrm{L} \mathrm{min}$ ); $90 \%-100 \%$ B at $245-255 \mathrm{~min}$ 
(flow rate $=20-80 \mu \mathrm{L} / \mathrm{min}$ ); and held for $10 \mathrm{~min}$ at $100 \%$ buffer B. Within the next $5 \mathrm{~min}$, the concentration of solvent $B$ was decreased to $0 \%$ and the column was equilibrated for 8 min at a flow rate of $80 \mu \mathrm{L} / \mathrm{min}$ and $7 \mathrm{~min}$ at a flow rate from 80 to $5 \mu \mathrm{L} / \mathrm{min}$ before the next injection.

The separation of components was monitored using a photodiode array detector at the 200-750 nm range and a mass spectrometer at the $100-1000 \mathrm{~m} / \mathrm{z}$ range. A positive electrospray ionization mode (ES+) with a TOF detector was used. The identification of components was performed by the analysis of the absorbance spectra in connection with mass spectra (Supplementary Figure S2) with the use of MassLynx 4.1 software (Waters). The chromatograms were presented at the wavelength characteristic for carotenoids $(470 \mathrm{~nm})$ and at the appropriate mass of identified components (Supplementary Figure S2).

\subsubsection{Gas Chromatography-Mass Spectrometry (GC-MS)}

The separation of single mass was performed using an Agilent 7890A Series Gas Chromatograph interfaced to an Agilent 5973c Network Mass Selective Detector and an Agilent 7683 Series Injector (Agilent Technologies, Palo Alto, CA, USA). A $5 \mu \mathrm{L}$ sample was injected with split 1:5 (sample/carrier gas) to an HP-5MS column (30 $\mathrm{m} \times 0.25 \mathrm{~mm}$ I.D., $0.25 \mu \mathrm{m}$ film thickness) using He as the carrier gas at $1 \mathrm{~mL} \mathrm{~min}^{-1}$. The ion source was maintained at $250^{\circ} \mathrm{C}$; the GC oven was programmed with a temperature gradient starting at $50^{\circ} \mathrm{C}$ (for $8 \mathrm{~min}$ ) and this was gradually increased to $325^{\circ} \mathrm{C}$ (for $10 \mathrm{~min}$ ) at $7{ }^{\circ} \mathrm{C} \mathrm{min}^{-1}$. Mass spectrometry analysis was conducted in the electron-impact mode at an ionizing potential of $70 \mathrm{eV}$. The mass spectra were recorded from the selected ion monitoring (SIM) mode. In the SIM mode, the GC-MS collected signals from the individual ions.

\subsection{Quantitative Analysis of Carotenoids}

Bacterial strains were cultivated in lysogeny broth (LB) and minimal medium M9 [48], supplemented $(0.5 \%(w / v))$ with beet molasses or yeast extract for four days in two different temperatures, i.e., $15^{\circ} \mathrm{C}$ and $25^{\circ} \mathrm{C}$. Both bacterial strains were cultivated in an initial volume of $100 \mathrm{~mL}$ in triplicate. Every day, triplicates of each strain were divided into two equal parts. Part of the culture (i.e., $50 \mathrm{~mL}$ ) was extracted and then measured spectrophotometrically using Evolution 260 Bio (Thermo Fisher Scientific, Waltham, MA, USA) to establish the maximum absorbance value. To determine the concentration of the crude carotenoid extract, the method of Liaaen-Jensen and Jensen was used [62]. The bacterial pellet was resuspended in $10 \mathrm{~mL}$ of acetone-methanol $(7: 2 v / v)$ solution, sonicated at ultrasonic cleaner for $5 \mathrm{~min}$ and filtered through Whatman filter paper (Whatman, Maidstone, United Kingdom). The absorbance of this extracted solution was measured spectrophotometrically at $453 \mathrm{~nm}$ and calculated according to Jensen's equation [62]. The remaining half of bacterial cultures (i.e., $50 \mathrm{~mL}$ ) was dried at $100^{\circ} \mathrm{C}$ for $24 \mathrm{~h}$ and weighed to obtain the dry mass weight information.

\subsection{Free Radical Scavenging Activity}

The DPPH (2,2-diphenyl-1-picrylhydrazyl) method was used to measure the free radical scavenging activity. The dilutions were prepared as followed: $2 \mathrm{~mL}$ of $0.1 \mathrm{mM} \mathrm{DPPH}$ in methanol was added to $2 \mathrm{~mL}$ of methanol containing different amounts of crude carotenoid extracts of ANT_H30 or ANT_H53B, i.e., to reach final concentrations of: $0.32,0.64,0.96,1.92,3.2$, and $4 \mathrm{ug} / \mathrm{mL}$ of carotenoids. The absorbance at $517 \mathrm{~nm}$ was measured spectrophotometrically (Evolution 260 Bio (Thermo Fisher Scientific)) after $30 \mathrm{~min}$. The scavenging of the DPPH radical (\%) was calculated according to the formula $\left(\left(A_{0}-A_{1}\right) / A_{0} \times 100\right)$, where $A_{0}$ is the absorbance of the control reaction and $A_{1}$ is the absorbance of reactions containing crude carotenoid extract from ANT_H30 or ANT_H53B [64].

\subsection{Nucleotide Sequence Accession Numbers}

The nucleotide sequences of the draft genomes of Planococcus sp. ANT_H30 and Rhodococcus sp. ANT_H53B were deposited in the GenBank (NCBI) database with the accession numbers NZ_VOBJ00000000 and NZ_VOBD00000000, respectively. 


\section{Conclusions}

Two Antarctic bacteria, Planococcus sp. ANT_H30 and Rhodococcus sp. ANT_H53B, were recognized as carotenoid producers. In-depth genomic and functional analyses revealed that these bacteria may use various compounds as a source of carbon and energy, including xenobiotics and waste materials from industrial production, e.g., molasses or yeast extract. Further genomic analyses identified the $\mathrm{crt}$ genes responsible for carotenoid biosynthesis. In the genome of ANT_H30, a gene cluster associated with the production of apocarotenoids was identified, while, in ANT_H53B, we found various crt genes enabling the biosynthesis of $\mathrm{C}_{40}$ carotenoids, such as lycopene, $\beta$-carotene, chlorobactene, and astaxanthin. Quantitative analyses of the produced metabolites indicated the possibility of using these bacterial strains for the production of carotenoids at low temperature, in which mesophilic bacteria are no longer active or produce low biomass. Additionally, it was shown that the produced crude carotenoid extracts had a significant ability to scavenge free radicals, which is meaningful for their possible future applications.

Supplementary Materials: The following are available online, Figure S1: Iron scavenging ability of GASN medium (negative control), supernatants obtained from cultures of ANT_H30 and ANT_H53B and deferoxamine mesylate salt (positive control). Figure S2: GC-MS chromatogram of ANT_H53B carotenoid extract with SIM mode set on: (a) $575.46 \mathrm{Da}$, (b) $577.48 \mathrm{Da}$, (c) $587.91 \mathrm{Da}$. Table S1: Summary of carotenoids identification performed using UPLC.

Author Contributions: Conceptualization, M.S. and L.D.; methodology, M.S., K.G., and M.G.; software, M.S.; validation, M.S., M.G., and L.D.; formal analysis, M.S. and L.D.; investigation, M.S., A.R., K.G., M.G., and A.S.; resources, A.S., M.G., K.G., L.D.; data curation, M.S., A.R., M.G.; writing一original draft preparation, M.S., A.R., and L.D.; writing-review and editing, M.S., A.R., K.G., M.G., A.S., and L.D.; visualization, M.S. and A.R.; supervision, L.D.; project administration, L.D.; funding acquisition, L.D. All authors have read and agreed to the published version of the manuscript.

Funding: This research was funded by the National Science Centre (Poland), grant number 2016/23/B/NZ9/02909.

Acknowledgments: We thank Jan Gawor from the DNA Sequencing and Oligonucleotide Synthesis Laboratory IBB Polish Academy of Science, where the DNA sequencing was carried out with the use of CePT infrastructure financed by the European Union-the European Regional Development Fund (Innovative economy 2007-13, Agreement POIG.02.02.00-14-024/08-00). We also thank Przemyslaw Decewicz and Mikolaj Dziurzynski for their assistance with genomic analyses and Robert Stasiuk for his assistance with GC-MS analysis.

Conflicts of Interest: The authors declare no conflict of interest. The funders had no role in the design of the study; in the collection, analyses, or interpretation of data; in the writing of the manuscript, or in the decision to publish the results.

\section{References}

1. Ruiz, B.; Chávez, A.; Forero, A.; García-Huante, Y.; Romero, A.; Sánchez, M.; Rocha, D.; Sánchez, B.; Rodríguez-Sanoja, R.; Sánchez, S.; et al. Production of microbial secondary metabolites: Regulation by the carbon source. Crit. Rev. Microbiol. 2010, 36, 146-167. [CrossRef]

2. Reis-Mansur, M.C.P.P.; Cardoso-Rurr, J.S.; Silva, J.V.M.A.; de Souza, G.R.; Cardoso, V.D.S.; Mansoldo, F.R.P.; Pinheiro, Y.; Schultz, J.; Lopez Balottin, L.B.; da Silva, A.J.R.; et al. Carotenoids from UV-resistant Antarctic Microbacterium sp. LEMMJ01. Sci. Rep. 2019, 9, 1-14. [CrossRef]

3. Dieser, M.; Greenwood, M.; Foreman, C.M. Carotenoid pigmentation in Antarctic heterotrophic bacteria as a strategy to withstand environmental stresses. Arctic. Antarct. Alp. Res. 2010, 42, 396-405. [CrossRef]

4. Tuncer, P.B.; Büyükleblebici, S.; Eken, A.; Taşdemir, U.; Durmaz, E.; Büyükleblebici, O.; Çoşkun, E. Comparison of cryoprotective effects of lycopene and cysteamine in different cryoprotectants on bull semen and fertility results. Reprod. Domest. Anim. 2014, 49, 746-752. [CrossRef]

5. Nagarajan, J.; Ramakrishnan, R.; Raghunandan, M.E.; Galanakis, C.M.; Krishnamurthy, N.P. Chapter 8-Carotenoids. In Nutraceutical and Functional Food Components-Effects of Innovative Processing Techniques; Galanakis, C.M., Ed.; Academic Press: Cambridge, MA, USA, 2017; pp. 259-296, ISBN 978-0-12-805257-0.

6. Sánchez, S.; Ruiz, B.; Rodríguez-Sanoja, R.; Flores-Cotera, L.B. Microbial production of carotenoids. In Microbial Production of Food Ingredients, Enzymes and Nutraceuticals; Elsevier: Amsterdam, The Netherlands, 2013; pp. 194-234, ISBN 9780857093431. [CrossRef] 
7. Sandmann, G. Carotenoids of biotechnological importance. In Advances in Biochemical Engineering/Biotechnology; Scheper, T., Ed.; Springer: Cham, Switzerland, 2015; Volume 148, pp. 449-467, ISBN 978-3-319-20107-8. [CrossRef]

8. Cavicchioli, R.; Charlton, T.; Ertan, H.; Omar, S.M.; Siddiqui, K.S.; Williams, T.J. Biotechnological uses of enzymes from psychrophiles. Microb. Biotechnol. 2011, 4, 449-460. [CrossRef]

9. Maj, A.; Dziewit, L.; Drewniak, L.; Garstka, M.; Krucon, T.; Piatkowska, K.; Gieczewska, K.; Czarnecki, J.; Furmanczyk, E.; Lasek, R.; et al. In vivo creation of plasmid pCRT01 and its use for the construction of carotenoid-producing Paracoccus spp. strains that grow efficiently on industrial wastes. Microb. Cell Fact. 2020, 19, 1-14. [CrossRef]

10. Kim, J.W.; Choi, B.H.; Kim, J.H.; Kang, H.J.; Ryu, H.; Lee, P.C. Complete genome sequence of Planococcus faecalis AJ003 T, the type species of the genus Planococcus and a microbial $\mathrm{C}_{30}$ carotenoid producer. J. Biotechnol. 2018, 266, 72-76. [CrossRef]

11. Umeno, D.; Tobias, A.V.; Arnold, F.H. Evolution of the $\mathrm{C}_{30}$ carotenoid synthase CrtM for function in a $\mathrm{C}_{40}$ pathway. J. Bacteriol. 2002, 184, 6690-6699. [CrossRef]

12. Atam, S.I.; Singh, L.; Dube, S.; Reddy, G.S.N.; Shivaji, S. Psychrophilic Planococcus maitriensis sp.nov. from Antarctica. Syst. Appl. Microbiol. 2003, 26, 505-510. [CrossRef]

13. Majumdar, S.; Priyadarshinee, R.; Kumar, A.; Mandal, T.; Dasgupta Mandal, D. Exploring Planococcus sp. TRC1, a bacterial isolate, for carotenoid pigment production and detoxification of paper mill effluent in immobilized fluidized bed reactor. J. Clean. Prod. 2019, 211, 1389-1402. [CrossRef]

14. Majidzadeh, M.; Fatahi-Bafghi, M. Current taxonomy of Rhodococcus species and their role in infections. Eur. J. Clin. Microbiol. Infect. Dis. 2018, 37, 2045-2062. [CrossRef] [PubMed]

15. Bej, A.K.; Saul, D.; Aislabie, J. Cold-tolerant alkane-degrading Rhodococcus species from Antarctica. Polar Biol. 2000, 23, 100-105. [CrossRef]

16. Espuny, M.J.; Egjido, S.; Mercadè, M.E.; Manresa, A. Characterization of trehalose tetraester produced by a waste lube oil degrader Rhodococcus sp. 51T7. Toxicol. Environ. Chem. 1995, 48, 83-88. [CrossRef]

17. Le, R.K.; Wells, T.; Das, P.; Meng, X.; Stoklosa, R.J.; Bhalla, A.; Hodge, D.B.; Yuan, J.S.; Ragauskas, A.J. Conversion of corn stover alkaline pre-treatment waste streams into biodiesel via Rhodococci. RSC Adv. 2017, 7, 4108-4115. [CrossRef]

18. Mahan, K.M.; Le, R.K.; Wells, T.; Anderson, S.; Yuan, J.S.; Stoklosa, R.J.; Bhalla, A.; Hodge, D.B.; Ragauskas, A.J. Production of single cell protein from agro-waste using Rhodococcus opacus. J. Ind. Microbiol. Biotechnol. 2018, 45, 795-801. [CrossRef] [PubMed]

19. Bell, K.S.; Philp, J.C.; Aw, D.W.J.; Christofi, N. The genus Rhodococcus. J. Appl. Microbiol. 1998, 85, 195-210. [CrossRef]

20. Chen, Y.; Xie, B.; Yang, J.; Chen, J.; Sun, Z. Identification of microbial carotenoids and isoprenoid quinones from Rhodococcus sp. B7740 and its stability in the presence of iron in model gastric conditions. Food Chem. 2018, 240, 201-211. [CrossRef]

21. Romaniuk, K.; Ciok, A.; Decewicz, P.; Uhrynowski, W.; Budzik, K.; Nieckarz, M.; Pawlowska, J.; Zdanowski, M.K.; Bartosik, D.; Dziewit, L. Insight into heavy metal resistome of soil psychrotolerant bacteria originating from King George Island (Antarctica). Polar Biol. 2018, 41, 1319-1333. [CrossRef]

22. Ravikumar, S.; Woo, H.M.; Choi, J.-i. Analysis of novel antioxidant sesquarterpenes (C35 terpenes) produced in recombinant Corynebacterium glutamicum. Appl. Biochem. Biotechnol. 2018, 186, 525-534. [CrossRef]

23. Perez-Fons, L.; Steiger, S.; Khaneja, R.; Bramley, P.M.; Cutting, S.M.; Sandmann, G.; Fraser, P.D. Identification and the developmental formation of carotenoid pigments in the yellow/orange Bacillus spore-formers. Biochim. Biophys. Acta-Mol. Cell Biol. Lipids 2011, 1811, 177-185. [CrossRef]

24. Hupert-Kocurek, K.; Guzik, U.; Wojcieszyńska, D. Characterization of catechol 2,3-dioxygenase from Planococcus sp. strain S5 induced by high phenol concentration. Acta Biochim. Pol. 2012, 59, 345-351. [CrossRef] [PubMed]

25. Li, H.; Liu, Y.H.; Luo, N.; Zhang, X.Y.; Luan, T.G.; Hu, J.M.; Wang, Z.Y.; Wu, P.C.; Chen, M.J.; Lu, J.Q. Biodegradation of benzene and its derivatives by a psychrotolerant and moderately haloalkaliphilic Planococcus sp. strain ZD22. Res. Microbiol. 2006, 157, 629-636. [CrossRef] [PubMed]

26. Jung, J.H.; Joe, M.H.; Kim, D.H.; Park, H.; Choi, J.I.; Lim, S. Complete genome sequence of Planococcus sp. PAMC21323 isolated from Antarctica and its metabolic potential to detoxify pollutants. Stand. Genom. Sci. 2018, 13, 1-9. [CrossRef] [PubMed] 
27. Palatinszky, M.; Herbold, C.; Jehmlich, N.; Pogoda, M.; Han, P.; Von Bergen, M.; Lagkouvardos, I.; Karst, S.M.; Galushko, A.; Koch, H.; et al. Cyanate as an energy source for nitrifiers. Nature 2015, 524, 105-108. [CrossRef]

28. Howden, A.J.M.; Preston, G.M. Nitrilase enzymes and their role in plant-microbe interactions. Microb. Biotechnol. 2009, 2, 441-451. [CrossRef]

29. Blasco, R.; Martínez-Luque, M.; Madrid, M.P.; Castillo, F.; Moreno-Vivián, C. Rhodococcus sp. RB1 grows in the presence of high nitrate and nitrite concentrations and assimilates nitrate in moderately saline environments. Arch. Microbiol. 2001, 175, 435-440. [CrossRef]

30. Akhtar, N.; Ghauri, M.A.; Akhtar, K.; Parveen, S.; Farooq, M.; Ali, A.; Schierack, P. Comparative analysis of draft genome sequence of Rhodococcus sp. Eu-32 with other Rhodococcus species for its taxonomic status and sulfur metabolism potential. Curr. Microbiol. 2019, 76, 1207-1214. [CrossRef]

31. Nguyen, Q.T.; Trinco, G.; Binda, C.; Mattevi, A.; Fraaije, M.W. Discovery and characterization of an F420-dependent glucose-6-phosphate dehydrogenase (Rh-FGD1) from Rhodococcus jostii RHA1. Appl. Microbiol. Biotechnol. 2017, 101, 2831-2842. [CrossRef]

32. Greening, C.; Ahmed, F.H.; Mohamed, A.E.; Lee, B.M.; Pandey, G.; Warden, A.C.; Scott, C.; Oakeshott, J.G.; Taylor, M.C.; Jackson, C.J. Physiology, biochemistry, and applications of F420- and Fo-dependent redox Reactions. Microbiol. Mol. Biol. Rev. 2016, 80, 451-493. [CrossRef]

33. Zhang, Y.; Qin, F.; Qiao, J.; Li, G.; Shen, C.; Huang, T.; Hu, Z. Draft genome sequence of Rhodococcus sp. strain P14, a biodegrader of high-molecular-weight polycyclic aromatic hydrocarbons. J. Bacteriol. 2012, 194, 3546. [CrossRef]

34. Chen, B.S.; Otten, L.G.; Resch, V.; Muyzer, G.; Hanefeld, U. Draft genome sequence of Rhodococcus rhodochrous strain ATCC 17895. Stand. Genom. Sci. 2013, 9, 175-184. [CrossRef] [PubMed]

35. Vikram, S.; Kumar, S.; Subramanian, S.; Raghava, G.P.S. Draft genome sequence of the nitrophenol-degrading actinomycete Rhodococcus imtechensis RKJ300. J. Bacteriol. 2012, 194, 3543. [CrossRef] [PubMed]

36. Franzetti, A.; Gandolfi, I.; Bestetti, G.; Smyth, T.J.P.; Banat, I.M. Production and applications of trehalose lipid biosurfactants. Eur. J. Lipid Sci. Technol. 2010, 112, 617-627. [CrossRef]

37. Stes, E.; Francis, I.; Pertry, I.; Dolzblasz, A.; Depuydt, S.; Vereecke, D. The leafy gall syndrome induced by Rhodococcus fascians. FEMS Microbiol. Lett. 2013, 342, 187-194. [CrossRef] [PubMed]

38. Anastasi, E.; MacArthur, I.; Scortti, M.; Alvarez, S.; Giguére, S.; Vázquez-Boland, J.A. Pangenome and phylogenomic analysis of the pathogenic actinobacterium Rhodococcus equi. Genome Biol. Evol. 2016, 8, 3140-3148. [CrossRef] [PubMed]

39. Hu, Y.; Morichaud, Z.; Chen, S.; Leonetti, J.P.; Brodolin, K. Mycobacterium tuberculosis RbpA protein is a new type of transcriptional activator that stabilizes the $\sigma$ a-containing RNA polymerase holoenzyme. Nucleic Acids Res. 2012, 40, 6547-6557. [CrossRef]

40. Michel, A.; Agerer, F.; Hauck, C.R.; Herrmann, M.; Ullrich, J.; Hacker, J.; Ohlsen, K. Global regulatory impact of ClpP protease of Staphylococcus aureus on regulons involved in virulence, oxidative stress response, autolysis, and DNA repair. J. Bacteriol. 2006, 188, 5783-5796. [CrossRef]

41. Wall, D.M.; Duffy, P.S.; DuPont, C.; Prescott, J.F.; Meijer, W.G. Isocitrate lyase activity is required for virulence of the intracellular pathogen Rhodococcus equi. Infect. Immun. 2005, 73, 6736-6741. [CrossRef]

42. Popova, A.V.; Andreeva, A.S. Carotenoid-lipid Interactions. In Advances in Planar Lipid Bilayers and Liposomes; Iglič, A., Rappolt, M., Kulkarni, C., Eds.; Academic Press: Cambridge, MA, USA, 2013; pp. 215-236. [CrossRef]

43. Molyneux, $\mathrm{P}$. The use of the stable free radical diphenylpicryl-hydrazyl (DPPH) for estimating antioxidant activity. Songklanakarin J. Sci. Technol. 2004, 26, 211-219. [CrossRef]

44. Asker, D.; Beppu, T.; Ueda, K. Unique diversity of carotenoid-producing bacteria isolated from Misasa, a radioactive site in Japan. Appl. Microbiol. Biotechnol. 2007, 77, 383-392. [CrossRef]

45. Vila, E.; Hornero-Méndez, D.; Azziz, G.; Lareo, C.; Saravia, V. Carotenoids from heterotrophic bacteria isolated from Fildes Peninsula, King George Island, Antarctica. Biotechnol. Rep. 2019, 21, 1-7. [CrossRef] [PubMed]

46. Ram, S.; Mitra, M.; Shah, F.; Tirkey, S.R.; Mishra, S. Bacteria as an alternate biofactory for carotenoid production: A review of its applications, opportunities and challenges. J. Funct. Foods 2020, 67, 103867. [CrossRef]

47. Asker, D. Isolation and characterization of a novel, highly selective astaxanthin-producing marine bacterium. J. Agric. Food Chem. 2017, 65, 9101-9109. [CrossRef] [PubMed]

48. Elbing, K.; Brent, R. Media preparation and bacteriological tools. Curr. Protoc. Mol. Biol. 2002, 59 , 1-7. [CrossRef] [PubMed] 
49. Bultreys, A.; Gheysen, I. Production and comparison of peptide siderophores from strains of distantly related pathovars of Pseudomonas syringae and Pseudomonas viridiflava LMG 2352. Appl. Environ. Microbiol. 2000, 66, 325-331. [CrossRef]

50. Schwyn, B.; Neilands, J.B. Universal chemical assay for the detection and determination of siderophores. Anal. Biochem. 1987, 160, 47-56. [CrossRef]

51. Sambrook, J.; Maniatis, T.; Fritsch, E.F.; Russell, D.W. Russell Molecular cloning: A laboratory manual, III; Cold Spring Harbor Laboratory Press: New York, NY, USA, 2001; ISBN 9781936113415. [CrossRef]

52. Martin, M. Cutadapt removes adapter sequences from high-throughput sequencing reads. EMBnet J. 2011, 17, 10. [CrossRef]

53. Aziz, R.K.; Bartels, D.; Best, A.A.; DeJongh, M.; Disz, T.; Edwards, R.A.; Formsma, K.; Gerdes, S.; Glass, E.M.; Kubal, M.; et al. The RAST Server: Rapid annotations using subsystems technology. BMC Genom. 2008, 9, 75. [CrossRef]

54. Wattam, A.R.; Davis, J.J.; Assaf, R.; Boisvert, S.; Brettin, T.; Bun, C.; Conrad, N.; Dietrich, E.M.; Disz, T.; Gabbard, J.L.; et al. Improvements to PATRIC, the all-bacterial bioinformatics database and analysis resource center. Nucleic Acids Res. 2017, 45, D535-D542. [CrossRef]

55. Altschul, S.F.; Madden, T.L.; Schaffer, A.A.; Zhang, J.; Zhang, Z.; Miller, W.; Lipman, D.J. Gapped BLAST and PSI-BLAST: A new generation of protein database search programs. Nucleic Acids Res. 1997, 25, 3389-3402. [CrossRef]

56. Overbeek, R.; Olson, R.; Pusch, G.D.; Olsen, G.J.; Davis, J.J.; Disz, T.; Edwards, R.A.; Gerdes, S.; Parrello, B.; Shukla, M.; et al. The SEED and the rapid annotation of microbial genomes using subsystems technology (RAST). Nucleic Acids Res. 2014, 42, D206-D214. [CrossRef] [PubMed]

57. Moriya, Y.; Itoh, M.; Okuda, S.; Yoshizawa, A.C.; Kanehisa, M. KAAS: An automatic genome annotation and pathway reconstruction server. Nucleic Acids Res. 2007, 35, W182-W185. [CrossRef] [PubMed]

58. Blin, K.; Shaw, S.; Steinke, K.; Villebro, R.; Ziemert, N.; Lee, S.Y.; Medema, M.H.; Weber, T. antiSMASH 5.0: Updates to the secondary metabolite genome mining pipeline. Nucleic Acids Res. 2019, 47, 81-87. [CrossRef]

59. Kanehisa, M.; Sato, Y.; Morishima, K. BlastKOALA and GhostKOALA: KEGG tools for functional characterization of genome and metagenome sequences. J. Mol. Biol. 2016, 428, 726-731. [CrossRef]

60. Liu, B.; Zheng, D.; Jin, Q.; Chen, L.; Yang, J. VFDB 2019: A comparative pathogenomic platform with an interactive web interface. Nucleic Acids Res. 2019, 47, 687-692. [CrossRef]

61. Jia, B.; Raphenya, A.R.; Alcock, B.; Waglechner, N.; Guo, P.; Tsang, K.K.; Lago, B.A.; Dave, B.M.; Pereira, S.; Sharma, A.N.; et al. CARD 2017: Expansion and model-centric curation of the comprehensive antibiotic resistance database. Nucleic Acids Res. 2017, 45, D566-D573. [CrossRef]

62. EUCAST European Committee on Antimicrobial Susceptibility Testing (EUCAST). Available online: http: //www.eucast.org (accessed on 30 January 2020).

63. Skupień, J.; Wójtowicz, J.; Kowalewska, Ł.; Mazur, R.; Garstka, M.; Gieczewska, K.; Mostowska, A. Dark-chilling induces substantial structural changes and modifies galactolipid and carotenoid composition during chloroplast biogenesis in cucumber (Cucumis sativus L.) cotyledons. Plant. Physiol. Biochem. 2017, 111, 107-118. [CrossRef]

64. Szakiel, A.; Voutquenne-Nazabadioko, L.; Henry, M. Isolation and biological activities of lyoniside from rhizomes and stems of Vaccinium myrtillus. Phytochem. Lett. 2011, 4, 138-143. [CrossRef]

Sample Availability: Samples of the carotenoids produced by both strains are available from the authors. 